Bull. Egypt. Soc. Physiol. Sci. Vol. (42) Issue (1), 90-100

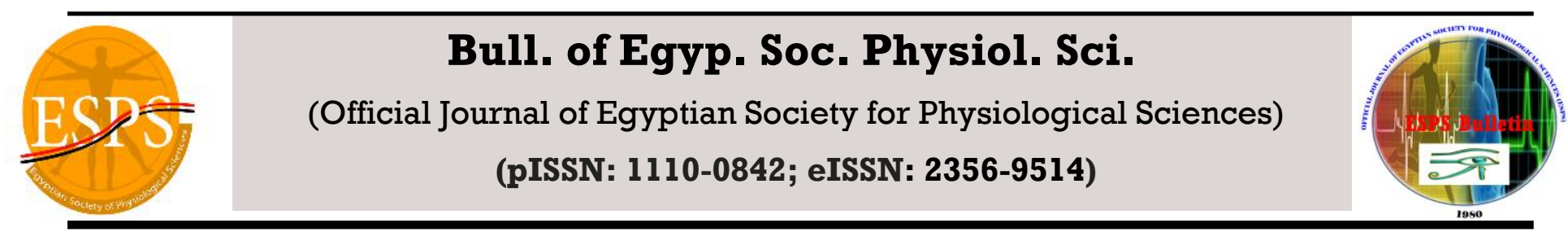

\title{
The Potential Role of Erythropoietin on Fatty Liver Induced By Methionine Choline Deficient Diet in Adult Male Rats
}

\author{
Hend A. Abdallah ${ }^{1}$, Hala M. Anwer ${ }^{1}$, Sherif W. Mansour ${ }^{2,3}$ and Mona A. Said ${ }^{1}$ \\ ${ }^{1}$ Physiology Department - Faculty of Medicine - Benha University, Egypt. \\ ${ }^{2}$ Physiology Department - Faculty of Medicine - Zagazig University, Egypt. \\ ${ }^{3}$ Faculty of Medicine, Mutah University, Jordan.
}

Submit Date: 8 July 2021

Revise Date: 10 Oct 2021

Accept Date: 19 Oct 2021

\section{Keywords}

EPO

NAFLD

MCD diet

- $\mathrm{TGF} \beta_{1}$

\begin{abstract}
With recent upsurge in obesity, the prevalence of nonalcoholic fatty liver disease (NAFLD) is growing globally. The objective of this study was to investigate the influence of erythropoietin (EPO) therapy on NAFLD and the role of transforming growth factor beta one (TGF $\beta 1$ ). NAFLD was induced in adult male albino Wistar rats by administration of methionine choline deficient (MCD) diet. Serum level of aspartate aminotransferase (AST), alanine aminotransferase (ALT), albumin, bilirubin, triglycerides (TG), total cholesterol (TC), body weight, liver weight and liver weight /body weight ratio were measured in different experimental groups to assess the liver affection. Liver samples were taken for measurement of TG, TC, malondialdehyde (MDA), reduced glutathione (GSH) and tumor necrosis factor alpha (TNF- $\alpha$ ) as well as histopathological detection of hepatic tissue injury and immuno-histochemical assessment of TGF $\beta 1$. As compared to the control group, MCD diet was found to produce a significant increase in serum level of AST, ALT, liver weight and liver weight/ body weight ratio, accompanied with a significant increase in liver tissue MDA, TNF- $\alpha$ and TGF- $\beta 1$ immuno-histochemical scoring. However, there was a significant decrease in hepatic GSH level. It also resulted in significant elevation in hepatic TG and TC, significant decrease in serum TG and TC levels and non-significant change in body weight, serum albumin and bilirubin. These results were supported by histopathological changes in hepatic tissues in the form of steatosis of hepatocytes and inflammatory cells infiltration. These results were reversed by EPO treatment. EPO treatment showed a hepato-protective effects against the development of NAFLD with a significant preservation of liver functions and structure that could be explained by the anti-oxidant, anti-inflammatory and anti-fibrogenic effect of EPO treatment.
\end{abstract}

Corresponding author: Mona A. Said, E.Mail: dr.monaabdelazim@gmail.com. Mobile: 002 01117060320. Address: Physiology department, Faculty of Medicine, Benha University, Egypt 


\section{INTRODUCTION}

Non-alcoholic fatty liver disease (NAFLD) became one of the most common forms of chronic liver disease surpassing viral hepatitis and alcohol induced liver disease. It affects over half a billion people worldwide. NAFLD represents a broad range of hepatic injuries, which advance from simple fatty liver to non-alcoholic steatohepatitis (NASH), cirrhosis or perhaps even hepatocellular carcinoma [1]. In research animals, a methionine choline deficient (MCD) diet can induce metabolic and histological phenotype similar to human fatty liver. Furthermore, this model causes fibrosing steatohepatitis and help in delineating the noninsulin resistant mechanisms involved in human steatohepatitis [2].

$$
\text { Erythropoietin (EPO), a hypoxia- }
$$

inducible hematopoietic glycoprotein secreted by the kidney, is well known principally for its physiological role in regulating erythropoiesis in the bone marrow [3]. Binding of EPO to its specific cell surface receptor (EPOR) mediates its biological effects [4]. EPOR are expressed in nonerythroid cells and tissues, including kidney, brain, pancreatic islet, liver, and endothelial cells [5]. Cumulative evidence asserts that EPO has additional organ protecting effects such as antioxidant, anti-inflammatory, anti-apoptotic and angiogenic properties [6]. EPO has been reported to exert a beneficial effect on glucose metabolism in obesity. However, its effect on non-alcoholic fatty liver disease (NAFLD) still unclear [7].

Consequently, this study was designed to investigate the possible advantageous roles of EPO treatment against NAFLD induced by MCD diet and to identify its possible protective mechanisms.

\section{MATERIAL AND METHODS:}

\subsection{Animals:}

This research study was conducted on 40 adult male albino Wistar rats, 6-8 weeks old, weighing between 190 and $220 \mathrm{~g}$. They were acquired from the Experimental Animal Unit of faculty of Veterinary medicine, Benha University. Animals were acclimatized to the laboratory environment for 10 days before beginning of the experiment. The rats were housed in isolated animal cages (5 rats/cage) with comfortable bedding on standard laboratory conditions (21 $25^{\circ} \mathrm{C}$ surrounding temperature, $50-60 \%$ relative humidity and $12-12 \mathrm{~h}$ light-dark cycle). All rats had free access to food and water. The study period continued for 14 weeks. Experimental rats were under full healthy conditions all over the experiment and under proper care of a professional technician. During the whole trial, no rats were dead. The animal procedures were performed in accordance with the guide to the care and use of experimental animals and approved by the Local Institutional Ethical Committee.

\subsection{Chemicals used:}

- Epoetin Vial: was purchased from (SEDICO pharmaceutical Co, Egypt, P001091).

- Diets used: MCD diet (Trophic Animal Feed High-Tech Co., Ltd., Nantong, China) containing amino acids, corn oil, fibers, vitamins, minerals, sodium bicarbonate, and tertiary butylhydroquinone (TBHQ) [8] and standard chow diet (cat no. 960441; ICN, Aurora, USA) Composed of the same constituents but supplemented with methionine and choline. 


\subsection{Experimental design:}

The rats were randomly classified into 4 equal groups ( $\mathrm{n}=10$ in each group). Group I (control group): they were fed a standard chow diet for 14 weeks and received intraperitoneal (i.p) phosphate buffered saline (PBS) as a vehicle every other day in the last 2 weeks. Group II (EPO group) they were fed a standard chow diet for 14 weeks and received $2000 \mathrm{IU} / \mathrm{kg}$ recombinant human EPO i.p. every other day in the last 2 weeks [9]. Group III (MCD diet group): received MCD diet for 14 weeks and received i.p injection PBS as a vehicle every other day in the last 2 weeks. Group IV (MCD diet + EPO): received MCD diet for 14 weeks and received $2000 \mathrm{IU} / \mathrm{kg}$ recombinant human EPO i.p. every other day in the last 2 weeks [9].

\subsection{Biochemical analysis:}

Estimation of serum AST, ALT, triglyceride (TG), total cholesterol (TC), albumin and bilirubin. Also, liver tissue TG and TC were done by commercial kits purchased from (Egyptian Company for Biotecnology, Obour City Industrial Area, Egypt). $5 \mathrm{~mL}$ of blood was obtained from abdominal aorta of anaesthetized rats using urethane $(120 \mathrm{mg} / 100 \mathrm{~g}$, i.p.) and centrifuged at 3000 r.p.m for $15 \mathrm{~min}$. Serum was separated to detect the aforementioned biomarkers according to Finley et al . [10]. Liver tissue TG and TC were determined by the same kit used for serum detection of TG and TC. Briefly, lipid was extracted using chloroform/methanol solution. The organic phase was collected and then vaporized, and the dry powder obtained was dissolved in isopropanol for the detection of hepatic TG and TC.
Estimation of tissue GSH by (Kamiya Biomedical Company Seattle, WA, U.S.A, ab65354) kits and tissue MDA was done by (Abcam biochemicals, Cambridge, UK, ab118970) kits according to manufacturer's instructions. Tissue TNF $\alpha$ level was assessed by an ELISA kit (Sigma-Aldrich Co., St Louis, MO, USA, $R A B 0476)$ and the absorbance was read at $450 \mathrm{~nm}$ by a microplate reader according to the manufacturer's instructions. TGF $\beta 1$ antibody was purchased from (ABCAM Company, Cambridge, $U K, a b 27969)$. Liver weight and body weight were measured and liver weight /body weight ratio was estimated by dividing the liver weight by body weight then multiply the resultant by 100 .

\subsection{Histopathological examination:}

Part of the liver was fixed in formaldehyde solution for 24 hours then dehydrated in ascending grades of ethanol and processed for paraffin wax embedding. Tissue samples were cut into $5 \mu \mathrm{m}$ thick sections using a Histo-Range microtome and stained with hematoxylin and eosin (H\&E). Liver tissue sections were examined under light microscope to examine the tissue damage based on the presence of steatosis of hepatocytes and inflammatory cells infiltration.

\subsection{Immunohistochemical TGF-ß1 scoring:}

The mean area $\%$ of TGF- $\beta 1$ immunoreaction of hepatocytes was tested throughout the ten high-control amplification $(\times 200)$ images of each study group utilizing software of Image-Pro Plus program rendition 6.0 (Media Cybernetics Inc., Bethesda, Maryland, USA).

\subsection{Statistical analysis:}

All analyses were performed using the program Statistical Package for Social 
Sciences version 19 (SPSS Inc, Chicago, IL, USA). The data were presented as the mean (M) \pm standard deviation (SD). Comparisons between groups were analyzed by using oneway Analysis of Variance (ANOVA) followed by post-hoc least significant difference (LSD) test. Probability of chance $(P$ value $)<0.05$ was considered statistically significant

\section{RESULTS:}

3.1. Serum AST, ALT, albumin and total bilirubin, tissue MDA, GSH and TNFa in all studied groups (Table 1):

- EPO treated group (group II) showed nonsignificant change in serum levels of AST, ALT, total bilirubin, and albumin, and tissue levels of MDA, GSH and TNFa (P $>0.05$ ) when compared with control group (group I).

- In group III (MCD diet group), MCD diet resulted in a significant elevation in serum levels of AST and ALT and hepatic tissue levels of MDA and TNF $\alpha(\mathrm{P}<0.05)$ while there was a significant reduction in hepatic tissue level of GSH $(\mathrm{P}<0.05)$ when compared with control group (group I). As regard serum total bilirubin and albumin, there was non-significant change $(\mathrm{P}$ > $0.05)$ as compared with the control group.

- Group IV (MCD diet + EPO) showed a significant reduction in the level of serum AST, ALT and tissue MDA and tissue $\mathrm{TNF} \alpha(\mathrm{P}<0.05)$, while there was significant increase in tissue level of GSH $(\mathrm{P}<0.05)$, there was also non-significant change in serum albumin \& bilirubin in when compared with MCD diet group (group III).

\subsection{Liver weight, body weight $\&$ liver weight} /body weight ratio in different experimental groups (table 2)

- EPO treated group (group II) showed nonsignificant change in liver weight, body weight and liver weight /body weight ratio $(\mathrm{P}>0.05)$ when compared with control group (group I).

- In group III (MCD diet group), MCD diet resulted in significant elevation $(\mathrm{P}<0.05)$ in liver weight, and liver weight /body weight ratio and non-significant change in body weight when compared with control group (group I).

- Group IV (MCD diet + EPO) showed a significant reduction in liver weight and liver weight /body weight ratio $(\mathrm{P}<0.05)$ and non-significant change in body weight when compared with MCD diet group (group III).

\subsection{Liver tissue TG, liver tissue TC, serum TG} and serum TC (Table 3)

- EPO treated group (group II) showed nonsignificant change in liver tissue TG, liver tissue TC, serum TG and serum TC $(\mathrm{P}>$ $0.05)$ when compared with control group (group I).

- In group III (MCD diet group), MCD diet resulted in significant elevation $(\mathrm{P}<0.05)$ in liver tissue TG, liver tissue TC levels and significant decrease in serum TG and serum TC when compared with control group (group I). 
- Group IV (MCD diet + EPO) showed a increase in serum TG and serum TC when significant reduction in liver tissue TG, liver tissue TC $(\mathrm{P}<0.05)$ and significant compared with MCD diet group (group III).

Table 1: Serum AST, ALT, albumin and total bilirubin, tissue MDA, GSH and TNF- $\alpha$ in all studied groups

\begin{tabular}{|c|c|c|c|c|}
\hline & $\begin{array}{c}\text { Group I } \\
\text { (control) }\end{array}$ & $\begin{array}{c}\text { Group II } \\
\text { (EPO) }\end{array}$ & $\begin{array}{c}\text { Group III } \\
\text { (MCD diet) }\end{array}$ & $\begin{array}{c}\text { Group IV } \\
\text { (MCD diet + EPO) }\end{array}$ \\
\hline AST (IU/L) & $45.72 \pm 6.52$ & $46.83 \pm 4.51$ & $94.56 \pm 12.66^{*}$ & $48.84 \pm 6.58 \#$ \\
\hline ALT (IU/L) & $50.79 \pm 6.03$ & $50.42 \pm 4.03$ & $80.76 \pm 9.32 *$ & $54.44 \pm 5.74 \#$ \\
\hline Albumin (g/dl) & $3.96 \pm 0.32$ & $3.66 \pm 0.62$ & $3.72 \pm 0.26$ & $3.82 \pm 0.46$ \\
\hline Bilirubin (mg/dl) & $0.84 \pm 0.15$ & $0.85 \pm 0.15$ & $0.85 \pm 0.22$ & $0.84 \pm 0.20$ \\
\hline $\begin{array}{c}\text { Mean tissue MDA } \\
\text { (nmol/gm tissue) }\end{array}$ & $1.13 \pm 0.07$ & $1.15 \pm 0.13$ & $5.44 \pm 0.14 *$ & $1.17 \pm 0.08 \#$ \\
\hline $\begin{array}{c}\text { Mean tissue GSH } \\
\text { (mg/gm tissue) }\end{array}$ & $41.76 \pm 2.53$ & $41.67 \pm 2.84$ & $12.44 \pm 1.63 *$ & $39.67 \pm 2.5 \#$ \\
\hline $\begin{array}{c}\text { Mean tissue TNFa (Pg/gm } \\
\text { tissue) }\end{array}$ & $37.43 \pm 5.03$ & $38.01 \pm 3.53$ & $55.71 \pm 3.95 *$ & $40.14 \pm 3.85 \#$ \\
\hline
\end{tabular}

Data were represented as Mean \pm SD

(*) $\mathrm{P}<0.05$ compared to group I (control group)

(\#) $\mathrm{P}<0.05$ compared to group III (MCD diet group).

Table 2: Liver weight, body weight $\&$ liver weight /body weight ratio in all studied groups

\begin{tabular}{|c|c|c|c|c|}
\hline & $\begin{array}{c}\text { Group I } \\
\text { (control) }\end{array}$ & $\begin{array}{c}\text { Group II } \\
\text { (EPO) }\end{array}$ & $\begin{array}{c}\text { Group III } \\
\text { (MCD diet) }\end{array}$ & $\begin{array}{c}\text { Group IV } \\
\text { (MCD diet + EPO) }\end{array}$ \\
\hline Liver weight (g) & $10.99 \pm 0.76$ & $11.69 \pm 0.56$ & $15.63 \pm 0.82 *$ & $11.27 \pm 0.89 \#$ \\
\hline Body weight (g) & $248.48 \pm 10.70$ & $250.28 \pm 8.60$ & $247.26 \pm 11.29$ & $249.54 \pm 5.53$ \\
\hline $\begin{array}{c}\text { Liver weight /body } \\
\text { weight ratio (\%) }\end{array}$ & $4.42 \pm 0.39$ & $4.67 \pm 0.39$ & $6.32 \pm 0.10^{*}$ & $4.51 \pm 0.38 \#$ \\
\hline
\end{tabular}

Data were represented as Mean \pm SD

(*) $\mathrm{P}<0.05$ compared to group I (control group)

(\#) $\mathrm{P}<0.05$ compared to group III (MCD diet group).

Table 3: TGFß1 immunohistochemical scoring, liver tissue TG, TC and serum TG and TC in all studied groups.

\begin{tabular}{|c|c|c|c|c|}
\hline & $\begin{array}{c}\text { Group I } \\
\text { (control) }\end{array}$ & $\begin{array}{c}\text { Group II } \\
\text { (EPO) }\end{array}$ & $\begin{array}{c}\text { Group III } \\
\text { ( MCD diet) }\end{array}$ & $\begin{array}{c}\text { Group IV } \\
\text { (MCD diet + } \\
\text { EPO) }\end{array}$ \\
\hline $\begin{array}{c}\text { TGFß1 immunohistochemical } \\
\text { scoring }\end{array}$ & $0.00 \pm 0.00$ & $0.00 \pm 0.00$ & $5.68 \pm 0.38^{*}$ & $3.29 \pm 0.49 \#$ \\
\hline liver tissue TG ( $\boldsymbol{\mu m o l} / \mathbf{g}$ liver) & $25.75 \pm 0.92$ & $26 \pm 0.087$ & $102 \pm 0.60^{*}$ & $38.87 \pm 0.95 \#$ \\
\hline liver tissue TC ( $\boldsymbol{\mu m o l} / \mathbf{g}$ liver) & $16.65 \pm 0.32$ & $15.89 \pm 0.5$ & $28.63 \pm 0.67 *$ & $21.85 \pm 0.42 \#$ \\
\hline Serum TG (mmol/L) & $0.75 \pm 0.28$ & $0.73 \pm 0.34$ & $0.57 \pm 0.42^{*}$ & $0.68 \pm 0.28 \#$ \\
\hline Serum TC (mmol/L) & $2.45 \pm 0.23$ & $2.33 \pm 0.19$ & $1.30 \pm 0.87 *$ & $2.26 \pm 0.68 \#$ \\
\hline
\end{tabular}

Data were represented as Mean \pm SD

(*) $\mathrm{P}<0.05$ compared to group I (control group)

(\#) $\mathrm{P}<0.05$ compared to group III (MCD diet group).

\subsection{Immunohistochemical examination results:}

The area\% of TGF- $\beta 1$ immunoreaction of hepatocytes was significantly higher $(\mathrm{P}<0.05)$ in MCD diet group figure (1-III) compared to control group figure (1-I) and EPO group figure (1-II) (immunopositivity indicated by brown color). Treatment with EPO in EPO+MCD diet group induced a significant decrease $(\mathrm{P}<0.05)$ in area\% of TGF- $\beta 1$ immunoreaction compared to MCD diet group as in figure (1-IV).

\subsection{Hematoxylin and Eosin results:}

Figure (2-I): control group (group I), liver sections showed a normal histological structure of hepatic tissue. Figure (2-II): group II (EPO group) 
liver sections showed a normal histological structure of hepatic tissue. Figure (2-III): group III (MCD diet group) liver specimen of rats received MCD diet alone exhibit fatty liver in the form of severe steatosis of hepatocytes and inflammatory cells infiltration. Figure (2-IV): liver sections of group IV (EPO + MCD diet) showed improvement as they exhibit minimal activation of Kupffer cells with very minimal hydropic degeneration of some hepatocytes.

Figure (1): The area \% of TGF- $\beta$ expression by immuno-histochemical staining
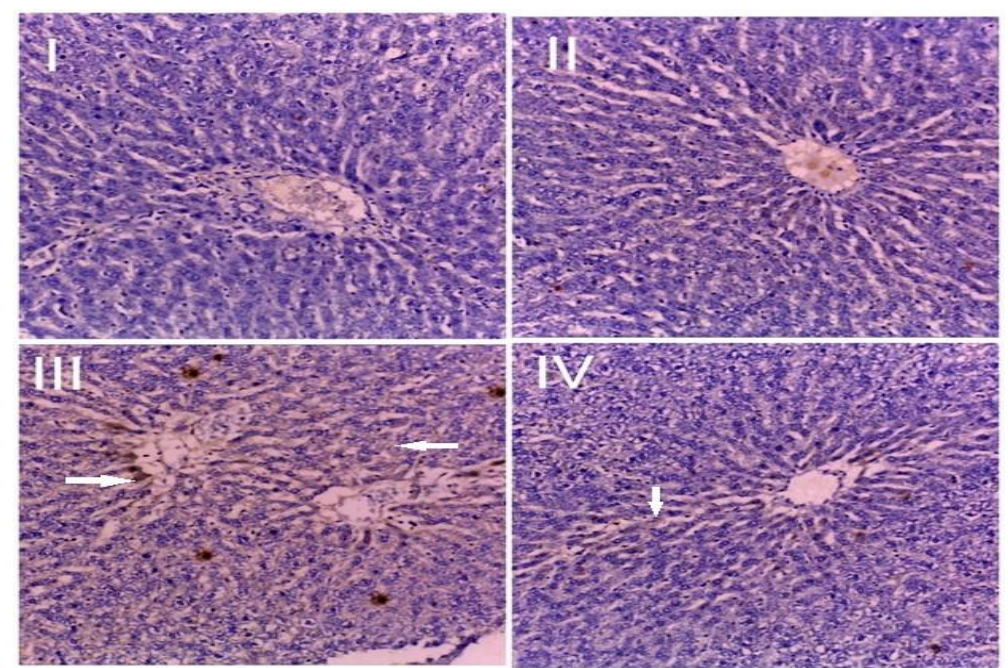

I: control , II : EPO group, III : MCD diet group and IV: MCD diet + EPO group

Figure (2): Histopathological findings in all studied groups
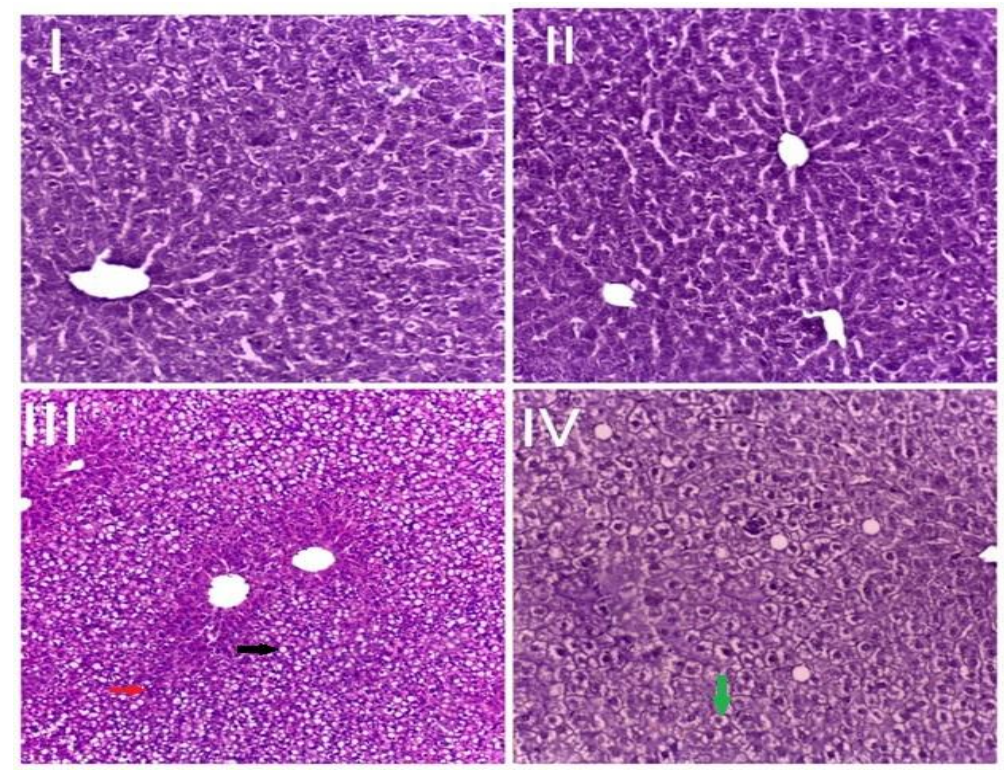

I: control, II: EPO group, III: MCD diet group and IV: MCD diet + EPO group

black arrow: Fat cells, red arrow: inflammation cell infiltration and Green arrow: hydroponic degeneration

\section{DISCUSSION:}

NAFLD is a common metabolic liver disease usually associated with obesity, type 2 diabetes, and metabolic syndrome. It is considered the most widespread liver disorder. It is defined as abnormal accumulation of lipids, principally in the form of triglycerides (TG), in individuals who do not consume significant amounts of alcohol $(\leq 20$ 
$\mathrm{g}$ ethanol/d). It includes a spectrum of disorders ranging from simple steatosis to non-alcoholic steatohepatitis [10].

EPO is a glycoprotein hormone that was originally identified as the humoral factor which controls production of erythroid precursor cells. However, many evidences suggest that EPO has several functions independent of its effects on red blood cells production. Recently, studies in vitro and vivo have shown that EPO attenuates cellular damage [11].

The current results proved the negative effect of MCD diet for 14 weeks on liver function. Group III (MCD diet group) showed significant elevation in serum levels of AST and ALT. On contrary, there were non-significant changes in serum albumin, total bilirubin \& body weight when compared with control group (group I). Additionally, significant increases $(\mathrm{P}<0.05)$ in liver weight and liver weight /body weight ratio were also observed between these groups. These results could be explained by the fact that the choline is an important element for formation of phosphatidylcholine, which is a critical component of very-low-density lipoproteins (VLDL), which are responsible for transporting TG out of the liver without affection of enzymes involved in de novo lipogenesis. Also, deficiency of choline leads to macro-vesicular steatosis so the liver weight increase without changes in the body weight [12]. Additionally, MCD diet was reported to induce NAFLD by triggering mitochondrial dysfunction which is a central mechanism in its pathogenesis [13]. In the MCD diet, the absence of methionine leads to hepatic injury, inflammation, and fibrosis. Therefore, the MCD diet mouse model has been used in several studies to induce NASH with or without fibrosis [14].

In this study, serum and liver TG and TC levels were detected to assess the effect of erythropoietin on the NAFLD. MCD diet resulted in significant elevation in liver hepatic TG and TC levels and significant decrease in serum TG and TC when compared with control group (group I). While, Group IV (MCD diet + EPO) showed a significant reduction in hepatic TG and TC. Moreover, significant increase in serum TG and serum TC when compared with MCD diet group (group III) that indicate inhibitory effect of erythropoietin on hepatic steatosis [3]. Lipid accumulation plays a pivotal role in liver injury. Also, proinflammatory cytokines as IL-6 and TNF$\alpha$ contribute to the progression of NAFLD. EPO has been widely used based on its antioxidant and anti-inflammatory properties. Recent studies showed that EPO pretreatment exerts antiinflammatory effects in rats [15], [16]. Moreover, EPO suppresses hepatic steatosis and obesity by and regulating lipid accumulation, inflammation, and fibrosis [17]. Concerning total bilirubin and albumin, they are usually kept at normal level in NASH and NAFLD while hyperbilirubinemia and hypo-albuminemia are seen only in cases associated with cirrhosis that developed in the end stage of the disease [18].

Group III (MCD diet group) also showed significant elevation in tissue levels of MDA and tissue TNF $\alpha(\mathrm{P}<0.05)$ while there was significant reduction in tissue level of GSH $(\mathrm{P}<0.05)$. Moreover, a strong positive expression of profibrogenic marker (TGF $\beta 1$ ) was found. These results were confirmed by the histopathological finding which showed fatty liver in the form of 
severe hepatocytes steatosis and inflammatory cells infiltration. These results were agreed with Fujii and Kawada. It was simply explained by oxidative stress process, which is strongly associated with NAFLD. Mitochondria are significant cellular sources of reactive oxygen species (ROS) [19]. Also, $\beta$-oxidation of fatty acids, appears to be the major source of ROS in hepatic metabolic disorders. The consequences of increased ROS production during NAFLD include the reprogramming of hepatic lipid metabolism, changes in insulin sensitivity, and modulation of inflammation by interacting with innate immune signaling. These effects suggest a central role of oxidative stress in the development and progression of NAFLD [17].

Our study also revealed the protective effect of EPO on NAFLD, there were significant decreases in the serum levels of AST and ALT, and tissue levels of MDA and TNF $\alpha$ while there was a significant increase in GSH tissue level in group IV (EPO + MCD diet group) when compared with group III (MCD diet group). Group IV also showed a moderate expression of profibrogenic marker (TGF $\beta 1$ ). These results were confirmed by the histopathological finding which showed improvement as they exhibit mild inflammatory cell infiltration with minimal hydropic degeneration of some hepatocytes. These results were agreed with Hong et al. who reported that pretreatment with EPO was protective against NAFLD in rats through its ability to decrease the magnitude of oxidative stress and lipid peroxidation as demonstrated by the reduction in MDA level as well as the elevation in GSH level in the hepatic tissues. One of the possible mechanisms is mediated through its antioxidant effect [8]. These results were consistent with Kodo et al. and Ge et al. who reported that EPO play a beneficial role in regulating lipid metabolism as well as inhibiting hepatic endoplasmic reticulum (ER) stress that contributes to the progression of steatosis in vivo and in vitro $[20,21]$. Other possible mechanisms of EPO mediated hepatoprotection against NAFLD were reduction of hepatic fibrosis and stimulation of hepatic angiogenesis [22].

EPO treatment in (group II) revealed a non-significant changes in the serum levels of AST, ALT, total bilirubin and albumin, tissue levels of MDA, GSH and TNF $\alpha$, liver weight, body weight, liver weight /body weight ratio as well as the level of profibrogenic marker TGF $\beta 1$ immunohistochemical scoring when compared with that of control group (group I). These results were also confirmed by photomicrograph of liver biopsy of EPO group which showed preserved normal histological structure of hepatic tissue. This indicates that EPO did not cause significant effects on liver functions, oxidative stress state, inflammatory state or hepatic tissue fibrosis and angiogenesis in normal rats [23]. Our results were in accordance with Lundby and Olsen who declared that metabolic, hormonal, and renal effects of exogenous EPO administration in healthy volunteers were small and did not seem to range beyond physiologically acceptable limits. They also found that acute injections of EPO in healthy volunteers did not affect TGF $\beta 1$ in muscle biopsies obtained after the EPO injections [24].

\section{CONCLUSION:}

In conclusion, EPO treatment showed a hepatoprotective effect against the development of NAFLD with a significant preservation of liver 
functions and structure and this protection can be explained by the anti-oxidant, anti-inflammatory, anti-fibrogenic effects of EPO treatment.

\section{Abbreviations:}

ALT, Alanine aminotransferase; AST, Aspartate aminotransferase; MCD, Choline deficient; EPO, Erythropoietin; IL, Interleukin; I.P, Intraperitoneal; NAFLD, Nonalcoholic fatty liver disease; NASH, Non-alcoholic steatohepatitis; TGF $\beta 1$, Transforming growth factor beta one; TC, Total cholesterol; TG, Triglycerides; TNF $\alpha$; tumor necrosis factor alpha; VLDL, Very low density lipoprotein.

\section{CONFLICT OF INTEREST:}

There is no conflict of interest.

\section{REFERENCES:}

1. Younossi, Z., Anstee, Q.M., Marietti, M., Hardy, T., Henry, L., Eslam, M., George, J., Bugianesi, E. (2018). Global burden of NAFLD and NASH: Trends, predictions, risk factors and prevention. Nat Rev. Gastroenterol. Hepatol., 15(1), 11 - 20. doi: 10.1038/nrgastro.2017.109.

2. Jorgačević, B., Mladenović, D., Ninković, M., Prokić, V., Stanković, M., Aleksić, V., Cerović, I., Vukićević, R., Vučević, D., Stanković, M., Radosavljević, T. 2014. Dynamics of oxidative/nitrosative stress in mice with methionine-cholinedeficient diet-induced nonalcoholic fatty liver disease. Hum. Exp. Toxicol. 33(7): 701 - 9. doi: 10.1177/0960327113506723.

3. Yien, Y.Y., Shi, J., Chen, C., Cheung, J.T., Grillo, A.S., Shrestha, R., Li, L., Zhang, X., Kafina, M.D., Kingsley, P.D., King, M.J., Ablain, J., Li, H., Zon, L.I.,
Palis, J., Burke, M.D., Bauer, D.E., Orkin, S.H., Koehler, C.M., Phillips, J.D., Kaplan, J., Ward, D.M., Lodish, H.F., Paw, B.H. (2018). FAM210B is an erythropoietin target and regulates erythroid heme synthesis by controlling mitochondrial iron import and ferrochelatase activity. J. Biol. Chem. 293(51): 19797 19811.

doi:

10.1074/jbc.RA118.002742.

4. Meng, R., Zhu, D., Bi, Y., Yang, D., Wang, Y. 2013. Erythropoietin inhibits gluconeogenesis and inflammation in the liver and improves glucose intolerance in high-fat diet-fed mice. PLoS One. 8(1): e53557. doi: 10.1371/journal.pone.0053557.

5. Jelkmann, W. (2010). Erythropoietin: Back to basics. Blood. 115(21): 4151 - 4152. doi: 10.1182/blood-2010-03-271395.

6. Wang, L., Di, L., Nouguchi, C.T. 2014. Erythropoietin, a Novel Versatile Player Regulating Energy Metabolism beyond the Erythroid System. Int. J. Biol. Sci. 10(8): 921 939. doi:10.7150/ijbs.9518.

7. Tsuma, Y., Mori, J., Ota, T., Kawabe, Y., Morimoto, H., Fukuhara, S., Kodo, K., Umemura, A., Nakajima, H., Hosoi, H. 2019. Erythropoietin and long-acting erythropoiesis stimulating agent ameliorate non-alcoholic fatty liver disease by increasing lipolysis and decreasing lipogenesis via EPOR/STAT pathway. Biochem. Biophys. Res. Commun. 509(1): 306 - 313. doi: 10.1016/j.bbrc.2018.12.131.

8. Hong, T., Ge, Z., Zhang, B., Meng, R., Zhu D., Yan, B. 2019. Erythropoietin suppresses hepatic steatosis and obesity by inhibiting endoplasmic reticulum stress and 
upregulating fibroblast growth factor 21. Int. J.

Mol. Med. 44(2), 469 - 478. doi: 10.3892/ijmm.2019.4210.

9. Finley, P.R., Tietz, N.W. (Eds.). 1996. Clinical guide to laboratory tests. 3rd edition. W.B. Saunders Co., Philadelphia. 578 - 580.

10. Leamy, A.K., Egnatchik, R.A., Young, J.D. 2013. Molecular mechanisms and the role of saturated fatty acids in the progression of non-alcoholic fatty liver disease. Prog. Lipid Res., 52(1): $165 \quad-\quad 174 . \quad \underline{\text { doi: }}$ 10.1016/j.plipres.2012.10.004.

11. She, J., Yuan, Z., Wu, Y., Chen, J., Kroll, J. 2018. Targeting erythropoietin protects against proteinuria in type 2 diabetic patients and in zebrafish. Mol Metab. 8: 189 202. doi: 10.1016/j.molmet.2017.

12. Kume, N., Torii, H., Yasuda, D., Shimizu, R., Hiraoka, Y. 2018. Serum lipid profiles in a mouse model of non-alcoholic steatohepatitis (NASH) induced by cholinedeficient high fat diet (MCDHFD). Atherosclerosis, $\quad 275: \quad$ E191. doi:https://doi.org/10.1016/j.atherosclerosis.20 $\underline{18.06 .585 .}$.

13. Albhaisi, S., Sanyal A. 2018. Recent advances in understanding and managing nonalcoholic fatty liver disease. F1000Res. 7: F1000 Faculty Rev-720. doi: 10.12688/f1000research.14421.1. eCollection 2018.

14. Kim, S.B., Kang, O.H., Lee, Y.S., Han, S.H., Ahn, Y.S., Cha, S.W., Seo, Y.S., Kong, R., Kwon, D.Y. 2016. Hepatoprotective Effect and Synergism of Bisdemethoycurcumin against MCD Diet-Induced Nonalcoholic Fatty Liver Disease in Mice. PLoS One. 11(2): e0147745. doi: 10.1371/journal.pone.0147745. eCollection 2016.

15. Liu, Q.S., Cheng, Z.W., Xiong, J.G., Cheng, S., He, X.F., Li, X.C. 2015. Erythropoietin pretreatment exerts antiinflammatory effects in hepatic ischemia/reperfusion-injured rats via suppression of the TLR2/NF- $\mathrm{B}$ pathway. In Transplant. Proc. 47(2): 283 - 289. doi: $\underline{10.1016 / j . t r a n s p r o c e e d .2014 .10 .045 . ~}$

16. Zhang, J., Zhao, D., Na, N., Li, H., Miao, B., Hong, L., \& Huang, Z. 2018. Reno protective effect of erythropoietin via modulation of the STAT6/MAPK/NF- $\kappa B$ pathway in ischemia/reperfusion injury after renal transplantation. international journal of molecular medicine. 10.3892/ijmm.2017.3204

17. Hong, W., Li, S., Wu, L., He, B., Jiang, J., Chen, Z. 2019. Prediction of VEGF-C as a Key Target of Pure Total Flavonoids From Citrus Against NAFLD in Mice via Network Pharmacology. Front Pharmacol. 10: 582. doi: 10.3389/fphar.2019.00582. eCollection 2019.

18. Smith, B.W., Adams, L.A. 2011. Nonalcoholic fatty liver disease and diabetes mellitus: pathogenesis and treatment. Nat. Rev. Endocrinol. 7(8): $456 \quad-465 . \quad \underline{\text { doi: }}$ 10.1038/nrendo.2011.72.

19. Fujii, H., Kawada, N. 2020. The Role of Insulin Resistance and Diabetes in Nonalcoholic Fatty Liver Disease. Int. J. Mol. Sci. 21(11): 3863. doi: 10.3390/ijms21113863.

20. Kodo, K., Sugimoto, S., Nakajima, H., Mori, J., Itoh, I., Fukuhara, S., Shigehara, K., Nishikawa, T., Kosaka, K., Hosoi, H. 2017. Erythropoietin (EPO) ameliorates 
obesity and glucose homeostasis by promoting thermogenesis and endocrine function of classical brown adipose tissue (BAT) in dietinduced obese mice. PLoS One. 12(3): e01736612017. doi:

10.1371/journal.pone.0173661. eCollection 2017.

21. Ge, Z., Zhang, P., Hong, T., Tang, S., Meng, R., Bi, Y., Zhu, D. 2015. Erythropoietin alleviates hepatic insulin resistance via PPAR $\gamma$-dependent AKT activation. Sci. Rep. 5: 178782015 . doi: 10.1038/srep17878.

22. Hong, T., Ge, Z., Meng, R., Wang, H., Zhang, P., Tang, S., Lu, J., Gu, T., Zhu, D., Bi, Y. 2018. Erythropoietin alleviates hepatic steatosis by activating SIRT1-mediated autophagy. Biochim. Biophys. Acta Mol. Cell Biol. Lipids. 1863: 595 - 603. https://www.sciencedirect.com/science/article/ abs/pii/S1388198118300428

23. Singbartl, G. 1994. Adverse events of erythropoietin in long-term and in acute/shortterm treatment. Clin. Investig. 72(6 Suppl): S36 - 43. PMID: 7950171.

24. Lundby, C., Olsen, N.V. 2011. Effects of recombinant human erythropoietin in normal humans. J. Physiol. 589(6): 1265 - 1271. https://physoc.onlinelibrary.wiley.com/doi/full /10.1113/jphysiol.2010.195917 